\title{
1990s' EXPERIENCE AND CULTURAL DIVERSITY MANAGEMENT
}

Leokadiya M. DROBIZHEVA, Dr. Sci. (His.), Chief Researcher, Head of the Center for the Study of Interethnic Relations, Institute of Sociology FCTAS RAS, Moscow, Russia.

\begin{abstract}
The article analyses the lessons that the state and society could learn from the institutional contradictions and violent conflicts that were overcome in Russia in the 1990s. Ethnic mobilization and ways of getting out of conflict situations are analyzed. Based on specific materials, it is shown that the most important lesson was the ability to find compromise, dialogue ways to remove contradictions in the field of language, ecology, requests for participation in the use of local natural resources, increasing independence in the economy, and developing culture.

Most of the controversy was related to the institutional sphere, violation of the constitution and federal laws. The author shows that the regulation of such conflicts in multi-component federations is facilitated by the understanding that the ethnic nationalism of elites in the republics is different. On the example of the analysis of the discourse and legislative practice of Bashkortostan, North Ossetia-Alania, Tatarstan and Tuva, it is shown that divided sovereignty (not secession) was discussed in Tatarstan, but in it, as in Sakha and Bashkortostan, economic and cultural nationalism, defensive in North Ossetia - Alania, mainly cultural in Tuva. Accordingly, the agreements between the government of the Russian Federation and the government of the republics differed. Compromise solutions were temporary and as soon as a strong legitimate government was formed in the Centre, they ceased to operate, this is also one of the lessons of the 1990s.

Interethnic contradictions within the republics were also achieved by compromise solutions. However, the problem of ensuring equal opportunities in the labour and political spheres still remains.

The lesson in preventing the escalation of power conflicts was the recognition of the legitimate monopoly of power on the part of the state. The protection of society is based on the rule of law, but compliance with the law needs control from both the state and society.

The final part of the article is devoted to the regulation of interethnic relations in the second decade of the 2000s. The author supports the idea of calling this process the management of cultural diversity, since the term nation-building used earlier contains a double understanding of the nation, both ethnocultural and civil.

The cited research results in the country and the republics show that ethnic identity remains very stable. But nowhere does it appear as a confrontational all-Russian identity, but is combined with it among the majority of the population. It can be assumed that the idea of the people as co-citizenship, aimed at consolidating social, spatial and ethnocultural communities, realizing their interests in the economy, politics, culture, contributes to the provision of solidarity in the country.

Keywords: ethnic mobilization • institutional and violent conflicts • ethnic nationalism • cultural diversity management $\bullet$ civil nationalism
\end{abstract}

DOI: $10.31857 /$ S013216250016783-4

This article is a translation of: Дробижева Л.М. Опыт 1990-х и управление культурным многообразием // Sotsiologicheskie Issledovaniia. 2021. No 8: 49-61. DOI: 10.31857/ S013216250015254-2

Introduction. The 1990s in multi-ethnic Russia, characterized by violent conflicts, spread of new ideas about federalism and tensions in inter-ethnic relations in national republics, are evaluated differently by the researchers and public figures. According to G.T. Toshchenko, that was the period of the establishment of ethnocracy, and its definition hides the pain for the 
Union fallen apart, built on the principles of internationalism ${ }^{1}$, and the past management based on the socialist centralism. Others called this time an ethnic revival, especially in the republics, where people began to speak their ethnic languages without hesitation in public places, on the street, in trams and shops. Historians and writers began to remember the cultural figures who were repressed or went abroad, ethnic folk songs were played at meetings and rallies. Such mobilizing moments were experienced not only by Bashkirs, Tatars, Chuvash people, Yakuts, Karelians, but also by ethnic Russians, who were happy, for example, that Shalyapin was again openly recognized as their respected singer and not as an emigrant, who was talked about more often at home, but about whom it was impossible to write a thesis at Moscow State University. Russian culture, which rose to international fame, has again become the property of Russian citizens.

From the standpoint of interdisciplinary scientific approaches and ethno-sociological point of view, the 1990s can be called the era of ethnic mobilization and ethnic nationalism. Analyzing the types of ethnic activity in the republics (primarily in Russia, but the experience of the former Soviet republics is also taken into account), we will try to formulate the lessons learned from the experience that are significant for managing the cultural diversity in different periods of the country's life. In our study, we took into account the theoretical elaboration of the events of the 1990s by scientists who then took a real part in the work of imperious institutions and regulation of conflict situations [Tishkov, 1997; Pain, 2004], the vision of the occurred transformations by government representatives [Abdulatipov, Mikhailov, 2016] and, of course, the work of national sociologists, conflictologists and ethnic psychologists, Yu.V. Arutyunyan, Zh.T. Toshchenko, A.G. Zdravomyslov, M.N. Guboglo, G.U. Soldatova, I.M. Lebedeva, etc., as well as our colleagues from the republics.

The ethno-sociological studies organized by the Institute of Ethnology and Anthropology of the Russian Academy of Sciences in Tatarstan, Bashkortostan, Tuva, Sakha (Yakutia), North Ossetia-Alania in 1994, 1996-1997 and 1998-1999, were the empirical basis of the analysis ${ }^{2}$. In addition to mass surveys, 230 in-depth interviews were conducted with the leaders and specialists $^{3}$, whose names were determined during population surveys by answering the question "Who expresses the interests of your people?" In addition, the speeches of politicians and ideologists were also studied. Comparison of the research results for different years allows us to trace the dynamics of the attitude of political actors and residents of the regions to the sovereignty of the republics, ideas of separatism, nationalism, self-determination and federalism.

Of course, within the framework of the article it is impossible to highlight all the complex processes mentioned above. For this reason, we decided to focus on the following three issues: 1) what can form the basis of ethnic mobilization; 2) how the nationalism was transformed in the 1990s during the strengthening of the federal state; 3 ) what makes it possible to effectively retain the escalation of conflicts and contradictions.

The basis of ethnic mobilization both in the Soviet republics and in the Russian autonomies in the 1990s was the demand proclaimed by national (ethnic) activists to preserve their ethnic languages. Language is the most sensitive ethnic integrator, perceived by people as a value. Moreover, the language requirements then had a social basis reflecting the social and political interests of local ethnic elites. Knowledge of the ethnic language became an advantage when taking up the managing positions. The head of the republic, for example, was obliged to speak the ethnic language, which, consequently, deprived the representatives of other ethnicities

This is the last article by L.M. Drobizheva in our journal. The editorial board left the author's text unchanged.

${ }^{1}$ Internationalism was then understood as the priority of proletarian and then public interests and equitable friendly relations between people of different nationalities.

${ }^{2}$ In each of these republics, the sampling included 1000 people (the random error ranged within 4-5\%). The respondents included both Russians and ethnic groups which gave names to the republics. Head L.M. Drobizheva

${ }^{3} 110$ of them were published in [Drobizheva, 1996]. 
who did not know the language of the republic, including Russians, of access to the top echelons of power in the region. Often, not only the administration employees, but also service employees had to know the ethnic language.

Answering the question "What do you have in common with people of your ethnicity?", $82 \%$ of urban and $85 \%$ of rural Ossetians, $77 \%$ of urban and $83 \%$ of rural Tatars, $72 \%$ of urban and $83 \%$ of rural Sakha, $78 \%$ of Tuvans in cities and $84 \%$ in villages answered that it is the language. About $70 \%$ of ethnic Russians in the republics then wanted their children to know the language of the so-called titular ethnic groups. The republican newspapers in the mid-1990s paid a close attention to the language topic. The ideological pressure was felt quite clearly: "...the Tatar language is seriously ill" 4 , "if it dies, then we will perish as a nation" [Khakimov, 1993]. At the same time, answering the question "What conditions are now necessary for your people to revive?", just over $40 \%$ answered the language support [Drobizheva et al., 1996: 265-266], while $80 \%$ of Tatars, more than $90 \%$ of Ossetians, up to $90 \%$ of Yakuts and $79 \%$ of Tuvans wanted their children to speak Russian.

Language requirements are the most sensitive, and the regulation of interests in this area is one of the barometers of the ability of the authorities to find dialog-oriented ways to solve the problems. In the nineties, such a decision was the adoption of the law on the language of the people, which gave the name to the republic, and the recognition of it as the second state language in the corresponding region. At the same time, the leaders of the republics had to convince the population that the interests of the "titular nation" were being realized, but not to the detriment of other peoples. For example, the President of Tatarstan M. Sh. Shaimiev spoke of "Tatars and Russians", "Russians and Tatars", which indicates that the interests of both contacting peoples are taken into account.

To find the compromise, dialog-oriented solutions in the field of language, ecology, and the use of natural resources is an important lesson of the 1990s. Unfortunately, there are also cases in the history of modern Russia when the contradictions were resolved by force, the Ossetian and Ingush armed conflict over disputed territories and the Chechen conflict. The latter largely derived from the hedonistic aspirations of a set of people claiming power, who were supported by a part of the elite, the activities of which depended on the authorities, and a significant part of ordinary Chechens, who were in solidarity with the elite due to their oppression in the past. The role of elites in the escalation of conflicts was described at the time by T.R. Gurr [Gurr, 1993] and Ch. Tilly [Tilly et al., 1975], V.A. Tishkov introduced this idea into the imperious discourse in our country [Tishkov, 1997].

One of the main lessons learned by Russia from the experience of violent conflicts was the recognition that only the state can recognize the legal monopoly of force. The protection of society is based on the rule of law, but its observance shall be controlled not only by the state, but also by society, in world practice it is called a democratic participation [Zenghaas, 2007: 40]. Thus, the legal monopoly of force, rule of law and compliance with the Constitution form the basis for violent conflict management.

Lessons from institutional conflicts. There have been more than a hundred unarmed conflicts in the former Soviet Union. Most of them were institutional and constitutional, i.e. the contradictions in them were reduced to legislative regulations reflecting the ideologies and interests of the opposing parties. In such confrontations, the ethnocultural differences do not by themselves delineate the inter-group boundaries (in the understanding of $F$. Barth), there are economic, political and some situational circumstances behind them. The ideologies and actions of the republican elites who confronted the Federal Center were associated with ethnic nationalism clearly expressed in the 1990s.

In the Soviet ideology, literature and everyday practice, the concept of "nationalism" had a clearly negative meaning. It was interpreted as a denial of the equality of people of different nationalities (ethnicities), the priority of one nation (ethnicity) or race over the rest. On the

${ }^{4}$ See: Tatar territories. 1995. October. No. 38. 
contrary, in the European languages, this phenomenon was devoid of such an estimated load, it was discussed, analyzed and critically comprehended by many authoritative researchers. The discrepancy between the declarations of the elites and real practice was exposed by E. Kedourie [Kedourie, 1971], condemned by E. Hobsbawm [1998: 305], sometimes ridiculed by E. Gellner [1991: 319]. However, the experience of others without studying their own did not allow to determine ab ovo the contradictions risen and learn a lesson.

In the 1960s $\mathrm{H}$. Kohn proposed to distinguish two types of nationalism: civil, or Western, nationalism based on the free self-determination of an individual, and Eastern, based on the ideas of the priority of ethnic interests based on history and culture [Kohn, 1967: 329-333]. The ideas and demands put forward by the ideologists in the Russian republics were closer to the second one.

The nationalism, according to most experts, presupposes the existence of a community, nation that has its own special qualities, its interests and values are prioritized over other interests and values, and most importantly, the nation should strive to achieve political sovereignty, at least some [Breuilly, 1983]. The nationalism observed in the Russian republics fully corresponds to this description, but it was not the same throughout the Russian space. The analysis of the requirements of regional elites and legislative practice in the republics give grounds to assert that the nationalism in Russia differed. This is one of the main lessons learned by the scientists and the authorities from the experience of unarmed institutional conflicts.

The desire for complete separation took place only in the Chechen Republic, whose elite called for sovereignty. In Tatarstan, although it was called a sovereign democratic state in the republican Constitution, expressing "the will and interests of the entire multinational people of the republic", ideologists in power circles were aware of the danger of nationalist ideas of exclusivity and intolerance, and therefore specifically emphasized: "protecting the culture of ethnic communities, teaching in their ethnic language" and "self-government up to sovereignty does not contradict the principle of respect for human rights" [Iskhakov, 1995: 53], i.e. they expressed themselves in the spirit of civil nationalism. This principle was also supported by the representatives of the Russian-speaking part of the region's community. In the 1990s, not only the All-Tatar Public Center (ATPC), the Committee for the Protection and Implementation of the Sovereignty of Tatarstan "Sovereignty" and the Tatar National Independence Party "Ittifak" were freely operating in Tatarstan, but also the Union of Officers of Tatarstan, "People's Power" pro-Russian organization in open opposition to the sovereignty of Tatarstan, political wing "Civil Union", pro-Russian reformist-oriented organization "Soglasie", communist organization "People's Front of Tatarstan".

There were more than 20 parties in North Ossetia, but they were formally created and ineffective [Gostieva, Dzadziev, 1995: 219, 229]. Six parties were registered in Tuva, but they were exclusively Tuvans. In Sakha (Yakutia), the idea of sovereignty was actively supported by the public associations "Sakha Kaskile" and "Sakha Omuk". At the same time, the reformist Democratic Party of Yakutia and the very large Communist Party of Sakha operated there. There was also a ethnic Russian public organization in the republic.

In Tatarstan, the idea of shared sovereignty recorded in doctrinal documents, was advanced at the official level. "For us," M.S. Shaimiev explained, "the sovereignty means the ability to voluntarily determine the share of powers that we reserve for ourselves and the share of powers that we delegate to Russia" ${ }^{5}$. In addition to the application for shared sovereignty, the authorities of the republic sought to handle property relationship, forms of management, standards of social, tax, price and investment policy, while, however, they left most of the enterprises in public ownership. The Federal Center, of course, was not ready for such a type of federalism, and the President of Tatarstan himself was aware that "we have run far ahead,

${ }^{5}$ Izvestia of Tatarstan. 1995. February 15. P. 1. 
and when the power in the Center becomes stronger, we will have to determine our relations in accordance with federal laws" 6 .

The President of Sakha (Yakutia) M. Nikolaev understood the nationalism in its Soviet meaning, and in an interview he told us that this word was brought by foreigners and journalists coming to the republic. Nevertheless, at the celebration of the fifth anniversary of the proclamation of the sovereignty of the republic, he said: "We have focused on the economic independence of the republic" 7 . The ideologists of Yakut nationalism spoke mainly for the right of "core nation on natural resources, land right, self-government, taking into account law of custom" ${ }^{8}$. To a lesser extent, they focused on the discussion of ethno-cultural problems of language and the "revival of traditions".

In North Ossetia - Alania, the essence of sovereignty was mainly reduced to the protection of the territory, which was due to the clash with Ingushetia and the South Ossetian conflict. Interview with the President of the Republic A. Kh. Galazov, and with ethnic activists are literally permeated with this idea.

The agreements between the governments of the Russian Federation and the republics ensured exit of the conflict relations with the Center in the mid-1990s. Since the situations and nationalisms in the republics had their own peculiarities, each such agreement was distinguished by its originality. Liberals criticized the conclusion of agreements with the republics, seeing in this the establishment of patron-client relations (N. Petrov, A. Melville). Nevertheless, in those conditions, the agreements played a positive role ${ }^{9}$, becoming a way to remove conflict relations: "Legal development is not a luxury, but a prerequisite for the peaceful resolution of conflicts" [Zenghaas, 2007]. The end in the settlement of constitutional conflicts was put by the decision of the Constitutional Court of the Russian Federation in 2000, which abolished the sovereignty of the republics. It happened when the Center became strong.

The declaration of sovereignty did not mean the secession of the territory. "Where will we go," the representatives of the Tatarstan administration told us in an interview at the time, "It's not just about the geolocation of the republic." Both in the Center and in the local communities it was understood that in 24 hours the Central Bank can block the flow of finance, without which the functioning of the economic and social spheres of the region is impossible. At the federal level as a whole, the mobilization around this requirement did not provide a sufficient level of political gain. Since the mid-1990s, the political parties have stopped using it for mobilization, realizing that the non-Russian population of the republics is less than $1 / 5$ of the total electorate, and by the end of the decade, the values of unification based on the principles of citizenship and a common interest in stabilization of the situation began to gain popularity in them. It is no coincidence that the political party "Our Home - Russia" was the leader in Tatarstan, Tuva and North Ossetia. At the same time, the idea of sovereignty in the form of demands for greater participation in the disposal of natural resources and making economic decisions was supported by more than $60 \%$ of the population of the republics $(57 \%$ in North Ossetia, 64\% in Tatarstan, 68\% in Sakha (Yakutia) and Tuva), including more than $40 \%$ of ethnic Russians.

The power elite of the republics, called ethnocracy in the Center, in the 1990s had the opportunity to use not only ethno-cultural values, languages and traditions, but also environmental interests and the ideas of democracy, which was interpreted as respect for the rights of the minority. The practice of conflict resolution was to provide an opportunity to express ethnic identity in the public arena while maintaining a balance between the interests of various social forces, which provided compromise, socio-cultural loyalty and cultural established

${ }^{6}$ Record of the speech of M. Sh. Shaimiev at the conference on federalism in 1995 at the Academy of Sciences.

7 Speech of M.N. Nikolaev // The Republic of Sakha. 1995. February 14.

8 U. Vinokurova, Day of Core Nation / / The Republic of Sakha. 1995. August 9

9 The surveys conducted in Tatarstan in 1994 showed, for example, that $60 \%$ of Tatars and $70 \%$ of Russians supported the signing of such an agreement [Drobizheva et al., 1996: 78]. 
relations. The constitutional contradictions arose and needed to be resolved not only at the level of the Center - constituent entities of the federation, but also at the level of inter-ethnic relations within the republics. Recognition of someone else's interests, other than their own, became a difficult problem for the regional elites. The ethnocracy that Zh.T. Toshchenko wrote about was a reality, and the governments in the constituent entities of the federation, if they wanted to remain legitimate, had to show the ability to dialogue ${ }^{10}$. At the same time, as the results of surveys showed, the equality of opportunities in the republics was not always observed. Not only ethnic Russians, but also the representatives of the ethnicities that gave the name to the republics, recognized that a person's ethnicity was important when accessing to power. In $199926 \%$ of Russians and $18 \%$ of Bashkortostan Tatars believed that the Bashkirs had more opportunities to get a well-paid job in the republic, and $44-49 \%$ of Tatars and ethnic Russians believed that the Bashkirs had more opportunities to take a senior position in the authorities. Among the Bashkirs, only 13-29\% agreed with this. It is noteworthy that in 2013 , the opinions on trend remained the same and changed for the better by no more than $10 \%$ for each indicator. What is the lesson to be learned from this? The experience of the 1990s suggests that both at the federal level and at the level of the constituent entities of the federation, the state is obliged to prevent social discrimination, including on ethnic grounds, and to strive to ensure the equality of opportunities in the labor, social and political spheres.

In the 1990s, the elites played a predominant role in the formation of mass sentiments. The ideas of the political, scientific, and artistic elites were broadcast by the media and educators, and in traditional societies also by the elders and "authoritative people". In mass surveys, we recorded the spread of a stable opinion about the tensions that were actively discussed by the media. At the same time, the participants of the in-depth interviews talked about the information war.

If the consequences of nonviolent conflicts were reduced to frustration, xenophobia and migration, then the violent ones were accompanied by victims and flows of refugees. The number of refugees and displaced persons from North Ossetia - Alania, for example, was estimated at about 100 thousand people, 600 people died. Only from the end of 1994 to April 1995, 302.8 thousand people left Chechnya ${ }^{11}$.

The factors and causes of violent and non-violent conflicts were discussed both in the 1990s and in the 2000s, both in our country and abroad. There are different approaches to their explanation, but the main thing that needs to be learned from this sad experience is that ethnic challenges and radical forms of their implementation took place under the weak power of the Center. At some historical period of time, there are changes in the potential of ethnic groups (the structural and functional model of T. Parsons), whose elites pretend to top positions, primarily in power. It was not only our case in the 1990s. Similar processes were observed in the 1970s in Belgium and Canada. After making claims for changes, the current situation can persist for quite a long time, as long as the central government is strong. But if it loses legitimacy, as it was in the USSR in the late 1980s and early 1990s, there is a chance for the implementation of claims, and then the escalation or relief of conflict situations depends crucially on the status of the central government. Actually, this is what we have observed in Russia. The legitimation of the central government in the late 1990s and early 2000s was followed by the legislative elimination of deviations in the Constitutions of the constituent entities of the federation that contradict the federal laws.

It was necessary to improve the management of a multi - ethnic society and it was the peculiarity of the new Russia of the 2000s, given that the Russian peoples had the experience of the Soviet period, when, albeit declaratively, they had their own statehood, and the experience of the 1990s, when the attempts of the democratic elite of the Center to build

10 The Government of Tatarstan, for example, in the 1990s removed 15\% surcharge for language proficiency and reduced the number of faculties in universities where teaching was in the Tatar language.

${ }^{11}$ A. Zheludkov. Disasters of Russia are refugees. Refugee disaster is poverty // Izvestia. 1995. April 19. 
federalism without ethnicity (eliminate the republics) met resistance in the regions, forcing them to look for compromise solutions. In addition, there were differences in the understanding of democracy. Among politicians and some scientists, the idea of democratic federalism as a non-ethnic federalism of civil equality remained. In contrast, the ideologists in ethnic republics associated democracy with the possibility of taking into account the ethno-cultural complexity in the constitutional and legal space of the country.

Managing cultural diversity. In the Russian sources, the state's policy in the field of interethnic relations is called nation-building. Such a policy is carried out in all countries, which should combine the diversity of languages, religions, ethnicities, races with the flexibility of compliance with common laws and a common civic identity. In this article, instead of the term "nationbuilding", the phrase "management of cultural diversity" will be used, since, in our opinion, it more accurately describes the Russian policy that moves away from multiculturalism, but preserves the recognition of cultural diversity and languages of peoples while guaranteeing the freedom of cultural choice to the citizens (everyone has the right to determine their own ethnicity) and at the same time directs the state's efforts to intercultural interaction, development of dialogue and trust between peoples and the state. The religious Convention on the Protection of National Minorities ratified in 1998 obliges Russia to comply with a number of norms.

The management of cultural diversity at the state level is possible if, contrary to the concepts of neoliberalism and postmodernism, the nation-state is accepted as a continuing norm of modern states. Without entering into a discussion about the negative consequences of etatism for the formation of a political nation (prevalence of informal rules, low interpersonal and institutional trust), we believe that the state and the formation of a single political nation remains a necessary form of social coalition under modern conditions.

The fundamental document in the management of cultural diversity is the Strategy of the State National (Ethnic) Policy of the Russian Federation for the period up to 2025, where the concept of "Russian nation" for the first time appeared in the doctrinal space of management. In the modern world, there are two understandings of a nation: a civil political nation and an ethnic ethnocultural nation. There are examples of the transformation of one into another, elements of both can be present in each of them, nevertheless, both exist. Many modern multicultural states have their own internal nations, which explains the existence of the concept of "nation of nations" [Tishkov, 2008].

The management of cultural diversity is aimed at strengthening the All-Russian nation as integrating the society, stimulating the intercultural interactions and development of a civil solidarity. For this purpose, the management apparatus ensures the inclusion of this topic in the educational process, media and Internet space and promotes the practices of public self-regulation (for example, spontaneously emerging forms of mutual assistance, especially relevant in the context of a pandemic). The success of strengthening national (all-Russian) identity in a multicultural country largely depends on taking into account the growing ethnic identity of both ethnic Russians and other ethnicities, its orientation in a constructive, rather than disintegrating direction. The experience of our country shows that at specific historical stages and under certain conditions, the ethnic identity could involve both positive and destructive consequences for different peoples.

The management of ethnocultural development in Russia involves taking into account all the diversity of our complex state, where there are national autonomies, core small ethnic groups, peoples such as Gypsies and Aysors, dispersed people of different nationalities, diaspora groups, and, finally, migrants, external and internal, that attract special attention of departments and experts. People of each identity differ in the level of development of their civic culture and the preservation of traditional relations, respectively, and their integration processes proceed at different pace and have their own uniqueness.

Within the framework of the article, it is difficult to consider in detail the entire complex of issues related to the ethnicity in connection with the social, economic, political, historical and cultural contexts in the regions. Therefore, we will focus on those of them that are directly 
related to the preservation of the unity of the nation. We will discuss them on the example of the republics that serve as a barometer of the state of interethnic relations in the country Tatarstan, Bashkortostan, Sakha (Yakutia).

Tatarstan has quite high ethnic solidarity. $68 \%$ of Tatars and $54 \%$ of ethnic Russians believe that "it is important for a person to feel part of their ethnicity" ${ }^{12}, 84 \%$ of Tatars and $78 \%$ of ethnic Russians feel a connection with people of their ethnicity. However, with such a high importance of ethnicity, quite favorable inter-ethnic relations are maintained in the republic: $77 \%$ of Tatarstan residents considered them "favorable and calm". Only $12 \%$ have experienced distrust and hostility due to ethnicity over the past year. This value was the same for both ethnic Russians and Tatars and coincided with the all-Russian indicator.

Maintaining favorable interethnic relations is the result of the high interest of the population in staying calm and smart policy of government bodies in difficult conditions. Since the 1990s, the All-Russian Tatar Public Center has been operating in the republic, fighting for the preservation of the Tatar language ${ }^{13}$. In addition, there are officially supported organizations of Tatars in Tatarstan, World Congress of Tatars, Russian National (Ethnic) and Cultural Movement of the Republic of Tatarstan, Assembly of Peoples of Tatarstan, which includes the organizations of Chuvash and other ethnicities, Kazan Human Rights Center and other public associations, including religious ones. Actually, the position of the republic's leadership and its relations with the federal center are of crucial significance. Tatarstan is headed by an authoritative leader among both Tatars and ethnic Russians. Under strong power the interethnic contradictions are contained and to a certain extent leveled by other events of the all-Russian and economic plan. "Today, Tatarstan is an advanced and economically successful region that consistently focuses on building a strong Russia," R.N. Minnikhanov said during the celebration of the 100th anniversary of the republic in 2020 , and in preserving interethnic harmony he noted the support of the federal center "and, first of all, our national leader Vladimir Putin"14. At the same time, the words of the head of the republic do not mean that the management of interethnic relations in the region is not required. The problem of preserving the ethnic languages is very acutely perceived in Tatarstan ${ }^{15}$, not only by activists, but also by $59 \%$ of Tatars, while $49 \%$ of Tatars consider Russian as their native (first) language.

The difficulty of managing the interethnic relations in neighboring Bashkortostan lies in the fact that it is the republic with the highest level of interethnic contacts, where the people who gave the name to the republic do not make up the majority. With a high level of ethnic identity (79\% of Bashkortostan residents confidently identify themselves by ethnicity, especially Bashkirs and Tatars), quite favorable relations are maintained in the republic (74-77\% of the population evaluated them this way). At the same time, Bashkirs are concerned about the preservation of their ethnic language and environmental problems that are becoming socio-political (it is enough to recall the protests related to the preservation of Kushtau).

12 Hereinafter there are the data of the 2020 surveys conducted by the Center for the Study of Interethnic Relations of the Institute of Sociology of the Federal Center of Theoretical and Applied Sociology of the Russian Academy of Sciences in cooperation with the RPO "Center for the Study of Discrimination, Extremism and Xenophobia of the Republic of Tatarstan".

${ }^{13}$ However, at the last congress of writers of Tatarstan, this organization was called "a marginal structure where elderly activists get nostalgic ...but there is no hope that it will become an intellectual center." See: "The collective farm left over from the Soviet period": is there a chance for a reboot of the Writers' Union of the Republic of Tatarstan? // BUSINESS online. 2021. February 28. URL: https://business gazeta-ru. turbopages.org/business-gazeta.ru/s/article/500731 (reference date: 03.04.2021).

14 Rustam Minnikhanov: The subject of our pride and confidence in the future / / The Republic of Tatarstan. 2020. May 25 Issue No. 74(28843). URL: http://rt-onNne.ru/predmet-nashejgordostH-uverennosti-v- budushhem/ (reference date: 03.04.2021).

${ }^{15}$ Now the problem of the All-Russian census has become relevant, in connection with which the question of the possibility of recording more than one ethnicity and giving an answer about two native languages is being discussed. 
Issues of ecology and natural resources are also relevant for the residents of Sakha (Yakutia). The demand for participation in the use of natural resources has been voiced by experts here since the 1990s. During the polls in 2020 89\% (92\% of Sakha and $86 \%$ of ethnic Russians) called "the participation of Yakut people in the use of resources in its territory important for the republic" 16 . At the same time, the language issues are not as acute in Yakutia as in Tatarstan and Bashkortostan. 35\% insisted on compulsory study of the Sakha language by school students of all ethnicities in 2020, almost half of the Sakha people supported the voluntary study of Sakha language at school. $75 \%$ rated interethnic relations in the region as favorable. According to the assurances of the head of the Republic A. Nikolaev "Yakutia has always been and remains a stronghold of Russian statehood in the vast expanses of the northeastern part of the country" ${ }^{17}$. Nevertheless, the importance of ethnicity is high here: $96 \%$ of Sakha and $88 \%$ of ethnic Russians feel close to people of their ethnicity, and its updating is higher than in the case of other collective identities (generational, religious, local).

In the Russian national republics, the strategies for the development of peoples are being developed, in connection with which there are discussions with an ethnic focus, which show that under the new socio-political conditions, as in the 1990s, the nationalisms in the republics differ. In Tatarstan, the focus is on the ethno-cultural stability through language and traditions. In Bashkortostan, the same ideas are voiced, but the concept of "Bashkir" in the proposed strategy is interpreted broadly: "If a person does not speak the Bashkir language, but at the same time feels like a part of this great people, is proud of its belonging, then this person is a Bashkir. Anyone who lives in Bashkortostan, values the republic and works for its benefit, has the right to consider itself a Bashkir" ${ }^{18}$. In fact, an attempt is being made in the republic to include elements of civil nationalism in the ideology. Although not all the Bashkir elite agrees with this, the innovation has already been introduced, and it is not accidental. For several years, the issue of civil nationalism as an ideology and practice of the state and management of culturally complex communities ("nation of nations") of our time has been discussed among the ideologists in Russia. And for more than one year, the legitimacy of the state in the modern world have been discussed in the pages of the journal "Russia in Global Politics". In particular, the idea is expressed that this requires a good source "rooted in a common sense of national belonging" [Lieven, 2020: 26]; "... the state makes legitimate and viable, first of all, the population with a sense of national identity, when each generation goes through a kind of everyday referendum on commitment and participation in this state as its Fatherland" [Tishkov, 2021].

Nationalism is based on the idea of the people as a co-citizen, and it is aimed at consolidating the civil nation ${ }^{19}$. Being implemented in the economy, politics, and culture, the nationalism ensures the solidarity of the people, especially under conditions of internal tensions or conflicts, and mobilization to defend the interests of the Fatherland. When V.V. Putin calls himself a nationalist, he means exactly this kind of nationalism. "I am the biggest nationalist in Russia," he said at Valdai Forum in 2014, " But the biggest, most correct nationalism is building the actions and policies in such a way that the people will benefit from it. And if the nationalism is understood as intolerance towards other people, chauvinism, it will destroy our country,

${ }^{16}$ Results of a joint study in 2020 of the Center for Strategic Studies under the Head of the Republic of Sakha (Yakutia) and the Center for the Study of Interethnic Relations of the Institute of Sociology of the Federal Research Center of the Russian Academy of Sciences.

${ }^{17}$ Speech of A. Nikolaev on the National Flag Day in 2020

18 R. Khabirov's speech at the $V$ World congress of Bashkirs in 2019 See: "Copying the experience of Tatarstan is a serious step back": The congress of Bashkirs adopted its strategy / / BUSINESS online. 2021. February 28. URL: https://www.business-gazeta.ru/article/498335 (reference date: 03.04.2021).

19 Such nationalism can also differ and sometimes allows discrimination against minorities and expansion [Lieven, 2015]. 
which was originally formed as a multinational and multi-confessional state" ${ }^{20}$. In 2018, he explained his position: "...I want Russia to be preserved, including in the interests of the Russian people. And in this sense, I said that I am the most correct, the most real nationalist and the most effective. But this is not a boorish nationalism, ... which leads to the collapse of our state. That's the difference"21.

In the country as a whole, in each constituent territory of the federation and in the mass consciousness, there are elements of different nationalisms. Recognizing this, it is easier to find understanding and build a mutually acceptable community of people with different cultures and religions. The management of cultural diversity is precisely aimed at combining the civil solidarity of all Russians with progressive elements of ethnic identity and patriotism, taking into account the real ethno-social and ethno-political practice.

Some conclusions. In complex multi-component societies, it is impossible to solve the issues of preserving consent without the participation of the state. The latter is expressed not only in the functioning of a special institution designed to regulate the interethnic relations (we have the Federal Agency for Ethnic Affairs), but also in the creation of social coalitions that ensure the legal norms of co-existence, activities for economic and organizational life support, maintaining a system of social institutions, including education, security, and violence prevention.

In modern societies that declare the principles of democracy, an important role is assigned to the participation of citizens in the regulation of social and ethnic contradictions. In Russia, there is a Council on Interethnic Relations under the President of the Russian Federation, expert councils in the Federation Council, State Duma, Federal Agency for Ethnic Affairs and administrative bodies of the constituent territories of the federation. There are more than nine hundred federal, regional and municipal national autonomies in the country, however, according to the surveys, no more than $4-9 \%$ of our citizens know about them, and even less take part in their activities. It is obvious that civil participation in the regulation of interethnic contradictions, whether it is the need for education in the ethnic languages, support or elimination of some traditions (which do not comply with the laws), conflict situations with migrants, non-discrimination by ethnic, religious principles, etc., should be broader. These can be public discussions of pending legislative and legal acts, volunteer movements in support of the public order in the city, municipal district, courtyards, participation of public initiative organizations in the educational institutions in order to maintain or eliminate the cultural differences in the course of joint actions.

A sense of solidarity, belonging to the fate of the Fatherland, responsibility for the present and future of what we call the All - Russian identity, civic consciousness, it is of fundamental, fundamental importance for multinational Russia. As the President of the Russian Federation specifically noted at the last meeting of the Council on Interethnic Relations, the ethnic identity can have not only a competitive, but also a positive, constructive orientation, and the all-Russian civil identity is quite compatible with such an identity ${ }^{22}$. When implementing the modern state projects, taking into account the experience of regulating contradictions and conflicts of the 1990s can become a useful guide that helps to find ways to strengthen the interethnic harmony and preserve the ethno-cultural and religious diversity of the country.

\section{REFERENCES}

Abdulatipov R.G., Mihailov V.A. (2016) Russia in the 21st Century: National Answer on the National Question. Moscow: Mezhdunarodnyj izdatelskiy tsentr "Ethnosocium". (In Russ.)

Breuilly J. (1993) Nationalism and the State. 2nd ed. Manchester: Manchester University Press.

\footnotetext{
${ }^{20}$ Meeting of the International Discussion Club "Valdai" / / President of Russia. 2014. October 24. URL: http://www.kremlin.ru/events/president/news/46860 (reference date: 03.04.2021).

${ }^{21}$ Meeting of the International Discussion Club "Valdai" / / President of Russia. 2018. October 18. URL: http:// www.kremlin.ru/events/president/news/58848 (reference date: 03.04.2021).

22 Meeting of the Council on Interethnic Relations / / President of Russia. 2021. March 30. URL: http:// www.kremlin.ru/events/president/news/65252 (reference date: 03.04.2021).
} 
Drobizheva L.M. (1996) The Elite of the Republics of the Russian Federation Says: L. Drobizheva's 110 Interviews with Politicians, Businessmen, Scientists, Cultural and Religious Figures, Leaders of the Opposition Movements. Moscow: Publishing house of the Institute of Ethnology and Anthropology named after N.N. Miklouho-Maclay of RAS. (In Russ.)

Drobizheva L.M., Aklaev A.R., Koroteeva V.V., Soldatova G.U. (1996) Democratization and Images of Nationalism in the Russian Federation in the 90s. Ed. by L.M. Drobizheva. Moscow: Mysl. (In Russ.)

Gellner E. (1991) Nations and Nationalism. Ed. by I.I. Krupnik. Moscow: Progress. (In Russ.)

Gostiyeva L.K., Dzadziev A.B. (1995) Ethnopolitical Situation in North Ossetia. In: Developing Electorate of Russia. Moscow: Publishing house of the Institute of Ethnology and Anthropology named after N.N. Miklouho-Maclay of RAS: 214-241. (In Russ.)

Gurr T.R. (1993) Minorities at Risk: A Global View of Ethnopolitical Conflicts. Washington: U.S. Institute of Peace Press.

Iskhakov D. (1996) Model of Tatarstan: pro et contra. Panorama-Forum. No. 1: 46-58. (In Russ.)

Kedourie E. (1971) Nationalism in Asia and Africa. London: Weidenfeld and Nicolson.

Khakimov R.S. (1993) Twilight of the Empire (On the Nation and the State). Kazan: Tatar Book Publishing House. (In Russ.)

Khobsbaum E. (1998) Nations and Nationalism after 1780. St. Petersburg: Aletheia. (In Russ.)

Kohn H. (1967) The Idea of Nationalism. New York: Collier-Macmillan.

Lieven A. (2015) Anatomy of American Nationalism. Moscow: Eksmo. (In Russ.)

Lieven A. (2020) Progressive Nationalism. Rossiya vglobalnoy politike [Russia in Global Affairs]. Vol. 18. No. 5(105): 25-42. (In Russ.)

Pain E.A. (2004) Ethnopolitical Pendulum: Dynamics and Mechanisms of Ethnopolitical Processes in postSoviet Russia. Moscow: Institut sotsiologii RAN. (In Russ.)

Senghaas D. (2007) The Civilization of Conflict: Constructive Pacifism as a Guiding Notion for Conflict Transformation. In: Austin A., Fischer M., Ropers N. (eds) Transforming Ethnopolitical Conflict: The Berghof Handbook. Moscow: Nauka: 35-50. (In Russ.)

Tilly Ch., Tilly L., Tilly R. (1975) The Rebellious Century 1830-1930. Cambridge, Harvard University Press.

Tishkov V.A. (1997) Essays on the Theory and Politics of Ethnicity in Russia. Moscow: Russkiy Mir. (In Russ.)

Tishkov V.A. (2021) Nation, Nationalism and Nation-building. Rossiya v globalnoy politike [Russia in Global Affairs]. Vol. 19. No. 2(108): 42-62. (In Russ.)

Tishkov V.A. (2008) Russia is a Nation of Nations (In Connection with the New Concept of National Policy). Byulleten seti etnologicheskogo monitoringa i rannego preduprezhdeniya konfliktov [Bulletin of Ethnological Monitoring and Conflict Early Preventing Network]. No. 78: 10-15. (In Russ.) 